\title{
The "Histone Mimicry" by Pathogens
}

\author{
Uwe Schaefere, ${ }^{1,4}$ Jessica S.Y. Ho, ${ }^{1,2,4}$ Rab K. Prinjha, ${ }^{3}$ and AleXander Tarakhovsky ${ }^{1,5}$ \\ ${ }^{1}$ Laboratory of Immune Cell Epigenetics and Signaling, \\ The Rockefeller University, New York, New York 10065 \\ ${ }^{2}$ Laboratory of Methyltransferases in Development and Disease, Institute of Molecular \\ and Cell Biology (IMCB), Singapore 138673 \\ ${ }^{3}$ Epinova DPU, Immuno-Inflammation Therapy Area, GlaxoSmithKline, \\ Medicines Research Centre, Stevenage SG1 2NY, United Kingdom \\ ${ }^{5}$ Correspondence: tarakho@mail.rockefeller.edu
}

\begin{abstract}
One of the defining characteristics of human and animal viruses is their ability to suppress host antiviral responses. Viruses express proteins that impair the detection of viral nucleic acids by host pattern-recognition receptors, block signaling pathways that lead to the synthesis of type I interferons and other cytokines, or prevent the activation of virus-induced genes. We have identified a novel mechanism of virus-mediated suppression of antiviral gene expression that relies on the presence of histonelike sequences (histone mimics) in viral proteins. We describe how viral histone mimics can interfere with key regulators of gene expression and contribute to the suppression of antiviral responses. We also describe how viral histone mimics can facilitate the identification of novel mechanisms of antiviral gene regulation and lead to the development of drugs that use histone mimicry for interference with gene expression during diseases.
\end{abstract}

Viral infection leads to a rapid onset of two major mutually antagonistic processes. Encounter of human or mouse cells with virus results in rapid activation of intracellular signaling networks that trigger expression of genes responsible for the elimination of the virus and the establishment of lasting antiviral immunity (Katze et al. 2002; Garcia-Sastre and Biron 2006; Kawai and Akira 2006). In turn, viruses can target the antiviral signaling events for the benefit of virus replication and long-term virus propagation (Katze et al. 2002; Garcia-Sastre and Biron 2006; Kawai and Akira 2006).

In the nucleus, virus-host antagonism evolves around key regulatory processes that govern gene transcription and DNA replication. The structural and nonstructural proteins of numerous viruses accumulate in the nuclei of infected cells, where they interact with distinct chromatin proteins, including histones, transcription factors, regulators of DNA repair, cell cycle transition, mRNA splicing, export, and catabolism (Nemeroff et al. 1998; Ballestas et al. 1999; Friborg et al. 1999; Fujimuro et al. 2003; Krug et al. 2003; You et al. 2004; Zhao and Elder 2005; Satterly et al. 2007; Ashour et al. 2009; Colpitts et al. 2011; Fonseca et al. 2012; Banerjee et al. 2013).

One of the most common antihost viral strategies involves the disruption of host protein-protein interactions by viral mimics of cellular proteins (Elde and Malik 2009; Davey et al. 2011; Tarakhovsky 2013). In particular, the inherent functions and properties of host signaling and regulatory networks make them extremely attractive targets for viral mimic-derived interference. For one, such networks typically rely on highly specific and dynamic protein-protein interactions to be able to quickly transmit information within the cell (Smock and Gierasch 2009; Stein et al. 2009). This is in part supported by the use of low-affinity protein-protein interactions that involve compact (3-20 amino acids long), degenerate and evolvable modules that have been defined as short linear motifs (SLiMs) (Diella et al. 2008; Davey et al. 2012; Edwards et al. 2012; Van Roey et al. 2012, 2013; Weatheritt et al. 2012a,b). Most of the binding specificity and affinity of a SLiM is embedded within a 2-5-residue-long core of amino acids. This paucity of amino acids limits the strength of SLiM-mediated interactions to a relatively low affinity range $(1-150 \mu \mathrm{M})$ that supports transiency and reversibility of SLiM-mediated protein-protein binding (Diella et al. 2008; Davey et al. 2012; Edwards et al. 2012; Van Roey et al. 2012, 2013; Weatheritt et al. 2012a,b; Dinkel et al. 2014).

The described features of SLiMs match well the features of the short protein-binding sequences within the aminoterminal domains of histone proteins (histone tail). The histone tail could be viewed as a collection of multiple overlapping SLiMs, with each motif (and its modification state) functioning as a discrete unit of information for histone-binding proteins (Fischle et al. 2003; Ruthenburg et al. 2007; Taverna et al. 2007). This feature of the histone tail may contribute to its unique capability to facilitate binding of numerous nonhistone proteins. However, the minimal size of the interacting histone sequences can potentially compromise the specificity. Therefore, it is tempting to speculate that histone-tail-dependent formation of the chromatin complexes relies on a kinetic proofreading mechanism that has been initially introduced by Hopfield (1974) and Ninio (1975) as a mechanism for

\footnotetext{
${ }^{4}$ These authors contributed equally to this work.

Copyright (C) 2013 Cold Spring Harbor Laboratory Press; all rights reserved; doi: 10.1101/sqb.2013.78.020339 
error correction in biochemical processes. This proofreading mechanism connects the small differences in binding energy of interacting partners and the amount of extra free energy required to generate the desirable reaction product. When undesirable reactants participate in a reaction, free energy consumption drives molecular circuits in cycles before completing the reaction (Hopfield 1974; Ninio 1975). It is plausible that the shortness of the histone tail and, even more, the minimal size of the functionally distinct histone tail subdomains, for example, H3K4 vs. $\mathrm{H} 3 \mathrm{~K} 9 \mathrm{vs}$. H3K27, increases the length of time and amount of energy required for formation of functional transcription complexes. Although it is important to keep the error rates of transcription complex assembly low, the potential multiplicity of error-correcting cycles may increase the potentially damaging effect of "foreign" histone-like sequences that, by competing with cognate histone sequences, may prolong proofreading at the expense of cell fitness. In essence, although highly useful for the diversity of the chromatin complexes, the paucity of the amino acid sequence within the histone tail may create an opportunity for interference with the histone-based chromatin complexes by endogenous or exogenous histone-like SLiMs.

Here, we provide evidence for the existence and functional relevance of viral histone mimics. We also show that synthetic compounds that resemble histone mimics are able to interfere with the formation of transcription protein complexes and gene expression in cells of various types. Our studies suggest that targets of pathogen-derived or synthetic histone mimics can lead to identification of critical regulators of gene expression associated with inflammatory and viral diseases.

\section{RESULTS AND DISCUSSION}

\section{Endogenous and Exogenous Histone Mimics}

The existence of histone-like SLiMs (histone mimics) in nonhistone proteins has been initially shown in our earlier findings that reveal the presence of the histone H3-like sequence within the histone methyltransferase G9a that catalyzes dimethylation at lysine 9 of histone H3 (Sampath et al. 2007). G9a bears a 163-ARKT-166 motif that strongly resembles the 7-ARKS-10 motif of its target $\mathrm{H} 3$ target residue (Fig. 1A, left). Consistent with the presence of the histone mimic, G9a can automethylate itself on lysine 165 (Sampath et al. 2007), and this methylation facilitates the formation of the G9a bound repressor complex with chromodomain-containing protein HP1 $\gamma$ (Fig. 1A, right) (Sampath et al. 2007). The H3like sequence in G9a is conserved in its homolog and heterodimerization partner GLP (Fig. 1A, left) (Tachibana et al. 2005; Sampath et al. 2007), although the two proteins share relatively poor primary sequence conservation in their amino-terminal domains. The initial discovery of histone mimics in G9a/GLP led to identification of numerous histone mimics in nuclear and nonnuclear proteins, where these mimics contribute to protein-protein interaction or protein stability (Lee et al. 2010, 2012; Donlin et al. 2012; Badeaux and Shi 2013; Shi et al. 2014).
The compactness and intrinsic evolutionary plasticity of SLiMs, including those that are present within histones, make them easy to imitate, thus enabling pathogen-derived SLiMs to compete with the host counterparts. The viral histone mimicry has been initially shown by identification of the histone H3-like sequence within the carboxy-terminal portion of the nonstructural protein 1 (NS1) derived from the H3N2 subtype of influenza A virus (Marazzi et al. 2012). We found that the carboxyterminal domain of the NS1 protein carries the sequence 226-ARSK-229 (Fig. 1B, yellow) that resembles the first four amino acids of the histone H3 protein 1-ARTK-4 (red; Fig. 1B, top). Strikingly, both of these sequences were localized to the unstructured terminal domains of their respective proteins, indicating that the NS1 histone-like sequence is present within a similarly disordered structural context as the histone $\mathrm{H} 3$ tail.

The NS1 protein has a key role in virus propagation by suppressing the type I IFN response during influenza infection (Garcia-Sastre et al. 1998; Wang et al. 2000). Interestingly, among the 2753 unique full-length NS1 sequences obtained from the Influenza Virus Resource (Bao et al. 2008), the H3N2 subtype of viruses appears to be the predominant carrier of the bona fide histone H3K4like sequence. In contrast, "tails" of NS1 proteins from other influenza subtypes vary significantly and display either no recognizable motifs or possess highly specific motifs, such as PDZ ligand (PL) motifs (Obenauer et al. 2006; Jackson et al. 2008; Thomas et al. 2011), or the sumoylation sequence within the NS1 tail of the H1N1 (1918) influenza A virus (Table 1) (Santos et al. 2013).

This NS1 tail diversity may contribute to unique features of the individual virus subtypes. The NS1 carboxyterminal tail domain has previously been implicated as a virulence factor for some avian influenza A viral isolates (Jackson et al. 2008). The PL motifs ESEV and EPEV, found in the NS1 carboxyl terminus from multiple avian-derived influenza strains, have been associated with several highly pathogenic human isolates such as H5N1 1997 and H5N1 2003, respectively (Obenauer et al. 2006; Jackson et al. 2008; Thomas et al. 2011). These PL motifs enable viral interference with the apoptotic death of the infected cells, thus contributing to viral virulence (Golebiewski et al. 2011). Contrary to avian viruses, commonly circulating and relatively low-pathogenic human viruses predominantly contain PL motif sequences RSKV (H3N2 isolates) or RSEV (H1N1 isolates) that do not bind to known PDZ domain-containing proteins (Obenauer et al. 2006; Thomas et al. 2011). Furthermore, the overall loss of the NS1 carboxy-terminal tail from low-pathogenic viruses resulted in major attenuation of the virus (Jackson et al. 2008).

In the H3N2 strain, the presence of the histone mimic may contribute to the unique ability of the virus to compete with the cognate histone sequences for their common binding partners, including those that have an important role in regulation of antiviral gene expression. In support of this model, we found that both the histone $\mathrm{H} 3$ tail and the H3N2 NS1 tail bind in a sequence-dependent fashion to the Pafl component of the polymerase-associated fac- 
A
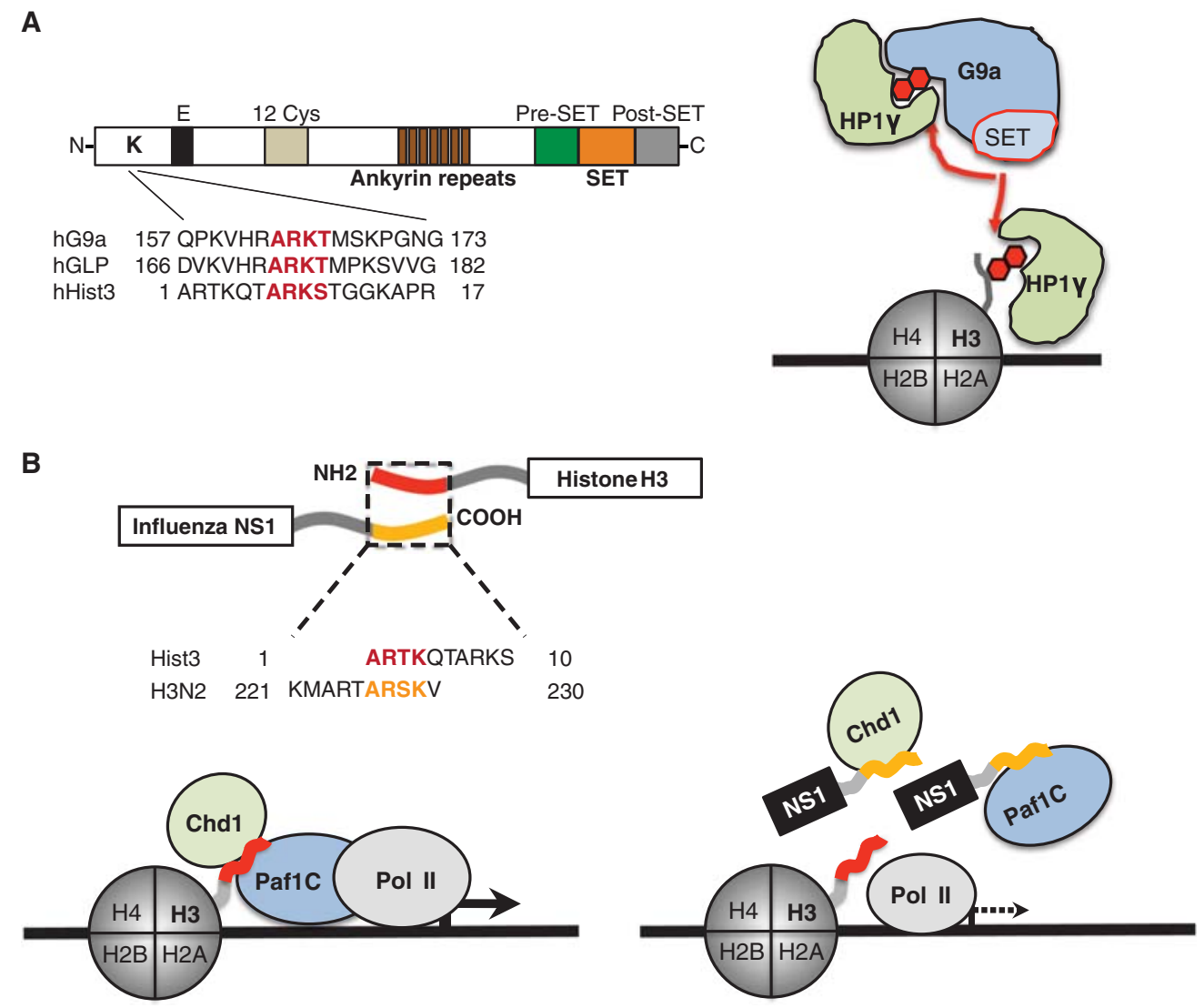

Figure 1. The structure and function of histone mimics. (A) Methyltransferases G9a and GLP possess a functional histone mimic. The histone-like sequence (red letters) is localized within the amino-terminal domain of the proteins (Sampath et al. 2007). The G9a histone mimic methylation (red hexagons) is mediated in cis by the catalytic SET domain (Sampath et al. 2007) that is flanked by preand post-SET domains. The ankyrin repeat domain is involved in G9a interaction with methylated histones (Collins et al. 2008), and the methylated histone mimic in G9a (red hexagons) binds to the chromodomain-containing protein HP1 $\gamma$ that can also interact with methylated histone H3 (red hexagon). (B) The NS1 proteins of the influenza A H3N2 virus possess a functional histone H3K4-like sequence. The histone-like sequence of NS1 (yellow letters) is localized within the nonstructured carboxyl terminus of the protein, whereas the homologous H3 sequence (red letters) is localized within the amino terminus of histone H3 (Marazzi et al. 2012). The NS1 histone mimic (yellow tails) is present in the nucleus (Greenspan et al. 1988), where it interacts with Pafl and Chd1 proteins. Interaction with Chd1 depends on NS1 lysine methylation, whereas Paf1 can bind to the unmethylated or methylated NS1 histone mimic. The pattern of Pafl and Chd1 binding to NS1 is similar to these protein interactions with histone H3. The schematic model describes a putative mechanism of NS1 interference with Paf1-mediated transcription of virus-induced genes.

tor 1 complex (Paf1C) that contributes to RNA elongation as well as other cotranscriptional processes (Marazzi et al. 2012). As expected, the NS1 tails from influenza H5N1 (Marazzi et al. 2012) and H1N1 (Marazzi and Tarakhovsky, unpubl.) that do not carry the histone mimic did not bind to Pafl.

Overall, the NS1 tail could be viewed as a highly interactive internally disorganized motif, where amino acid variations contribute to target specificity and hence to the unique features of individual virus subtypes. One of the extreme extensions of this model is that the diversity of the entire NS1 tails collection of the global influenza pool matches the diversity of the histone tails as well as other "tail"-like disordered structures in other host proteins. This feature of NS1 may support the influenza subtypes' ability to choose their optimal strategy

Table 1. The heterogeneity of the NS1 histone-like tails in influenza A subtypes

\begin{tabular}{llll}
\hline Strain & Year of appearance & \multicolumn{1}{c}{ NS1 carboxyl terminal } \\
\hline H3N2 & $1968-2014$ & 216 PKQKRKMART ARSKV & 230 \\
H1N1 & $1933-2014$ & 216 PKQKRKMART IRSE V & 230 \\
H5N1 & 2003 & 216 PNQKRKMART IESE V & 230 \\
H1N1 & 1918 (pandemic) & 216 PKQKRKMART IKSE V & 230 \\
H1N1 & 2009 (pandemic) & 216 PKQK & 219 \\
\hline
\end{tabular}

The NS1 tails of the displayed influenza A subtypes vary at amino acid positions 217 and 226-229 (boxed). The bona fide H3K4-like sequence in NS1 of the influenza A H3N2 virus (226-229) is shown in yellow. The sumoylation sequence within the NS1 tail of the influenza A H1N1 1918 virus is shown in blue. 
for the host-pathogen interaction, based on the genetic and epigenetic state of the infected host during the emergence of infection. In turn, the counterselection against certain viral subtypes, including some of the NS1 tail-less viruses, could be explained by the inability of NS1 to match the host factor(s), including those localized in the cell nucleus. Most provoking could be a consideration of the existence of the unique hostbinding partner(s) for the sumoylated NS1 of the 1918 Spanish flu that was "removed" from the human population due to the exceptionally high morbidity of Spanish influenza.

\section{Viral "Histone Mimics" Reveal Novel Regulators of Antiviral Response}

NS1 binding to Paf1, although apparently specific for H3N2, may offer a clue for understanding the general mechanism that governs antiviral transcriptional responses. Paf1 is an obligate member of the multiprotein Paf1 complex that contributes to RNA elongation (Kim et al. 2010 ) in addition to other cotranscriptional processes. The latter include transcription-coupled histone modifications (Wood et al. 2003; Kim and Roeder 2009; Hahn et al. 2012) and regulation of mRNA $3^{\prime}$ end processing (Mueller et al. 2004; Penheiter et al. 2005; Nordick et al. 2008; Rozenblatt-Rosen et al. 2009; Nagaike et al. 2011). In particular, the Paf1C has been shown to impact monoubiquitylation of histone H2BK120 in human cells by promoting recruitment of the ubiquitin-conjugating enzyme Rad6 and the ubiquitin protein ligase Bre1 to chromatin (Wood et al. 2003; Kim and Roeder 2009). Rad6/Bre1mediated monoubiquitylation of H2BK120 facilitates H3K4 trimethylation and H3K79 dimethylation by the Set1/MLL-1 and Dot1 complexes, respectively (Dover et al. 2002; Sun and Allis 2002; Kim and Roeder 2009; Nakanishi et al. 2009).

By binding to Paf1, the NS1 protein has the potential to interfere with multiple transcriptional processes, including those that support antiviral gene expression (Fig. 1B, bottom). Indeed, truncation of the Pafl-binding-NS1 sequence decreased virus ability to suppress antiviral gene expression and attenuated influenza infectivity in vitro (Marazzi et al. 2012). Conversely, the association with NS1 points to an important role of Paf1C in antiviral transcriptional response.

In the course of cell infection with the influenza virus that lacks NS1 and hence does not interfere with Pafl function, Pafl is recruited de novo to $\sim 200$ genes associated with antimicrobial and antiviral response, including numerous type I/III IFN-stimulated genes (ISGs) (Fig. $2 \mathrm{~A}-\mathrm{C})$. The virus-induced recruitment of Pafl correlates with recruitment of RNA Poll II and an increase in Paf1bound gene expression levels (Fig. 2C-E). Accordingly, the siRNA-mediated knockdown of Pafl suppressed selectively the expression of genes that recruit Pafl during infection but did not affect the expression of the majority of the $\sim 10,000$ genes that bind Pafl in a noninducible fashion (Fig. 2F).
The ability of the NS1 histone mimic to interact with host nuclear proteins could be expanded by its posttranslational modification. Similar to histone H3, the lysine residue within the NS1 histone mimic could be acetylated or methylated in influenza-infected cells (Marazzi et al. 2012). Although this methylation appears to have no obvious impact on the NS1-Paf1 interaction, the lysine methylation of NS1 supported its interaction with the chromatin-remodeling protein Chd1 (Marazzi et al. 2012). Moreover, the affinity of the methylated NS1 interaction with Chd1 is nearly equal to the affinity of Chd1 binding to the methylated lysine 4 of histone H3. Despite tight association of Chd1 with NS1, the siRNA-mediated deficiency of Chd1 had no effect on virus-induced gene expression. However, combined Pafl and Chd1 deficiencies resulted in a nearly complete abrogation of antiviral gene expression and 50-fold increase in influenza virus replication in vitro (data not shown). The major negative and cumulative effect of Chd1 and Pafl deficiencies on antiviral defense may reflect the Chd1 and PaflC interaction (Simic et al. 2003) that has been implicated in control of pre-mRNA splicing (Sims et al. 2007). NS1 interaction with Chd1 may provide the virus with access to the host splicing machinery and contribute to viral mRNA splicing and hence to viral replication (Chua et al. 2013).

Paf1C and associated proteins contribute to replication of human adenovirus (HAdV). During HAdV infection, E1A recruits Paf1C to the viral genome via Bre1, thus promoting viral early gene expression (Fonseca et al. 2013). The interaction of E1A with Bre1 was also shown to inhibit the expression of IFN and ISGs, suggesting that Rad6/Bre1-mediated ubiquitylation of H2BK120 was important for the expression of these genes (Fonseca et al. 2012). Given that the Paf1 complex also facilitates Rad6/Bre1 activity, these data support the notion that Paf1C and its related activities are key regulators of inflammatory response. Binding of the HIV protein TAT to Paf1C has also been implicated in generating the permissive transcription environment for HIV replication (Sobhian et al. 2010). Reduced levels of HIV proviral integration in cells that overexpress Pafl highlighted the importance of Pafl expression in the HIV viral life cycle (Liu et al. 2011).

\section{Functional Similarity between Synthetic and Natural Histone Mimics}

The important role of Paf1C in up-regulation of virusinducible gene expression corroborates well with earlier data that showed the key role of transcriptional elongation in inflammatory gene expression. RNA elongation depends greatly on signal-induced lysine acetylation of histone $\mathrm{H} 3$ and $\mathrm{H} 4$ at gene promoters followed by the acetylated histone association with bromodomain and the ET domain (BET) family of proteins (Hargreaves et al. 2009). The interaction between BET and acetylated histones is mediated by the evolutionary conserved $\sim 110$ amino-acid-long bromodomain that is present in each of the two tandem arranged modules (BDI and BDII) in 
A



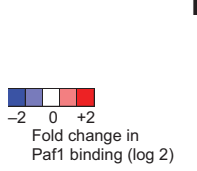

Paf1 binding (log 2)

B

\begin{tabular}{ll}
\hline \multicolumn{1}{c}{ Term } & $p$ value \\
\hline Response to virus & $3.0 \mathrm{E}-10$ \\
Response to other organism & $2.3 \mathrm{E}-08$ \\
Response to biotic stimulus & $1.3 \mathrm{E}-07$ \\
Apoptosis & $1.4 \mathrm{E}-05$ \\
Response to stimulus & $3.0 \mathrm{E}-05$ \\
\hline
\end{tabular}

C

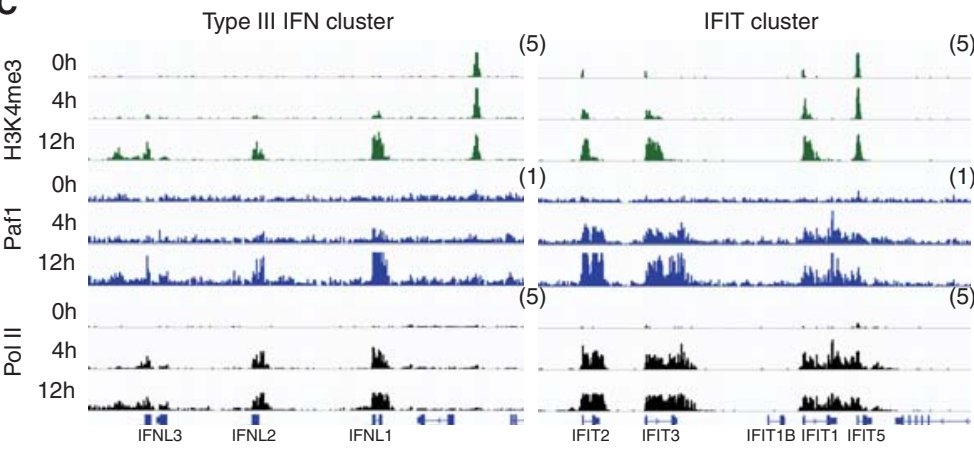

D



Pol-II-binding fold change $12 \mathrm{~h} / \mathrm{O} \mathrm{h}(\log 2)$
$\mathbf{E}$

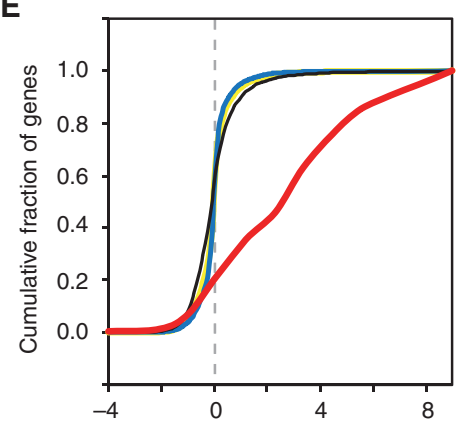

Expression fold change $12 \mathrm{~h} / 0 \mathrm{~h}(\log 2)$
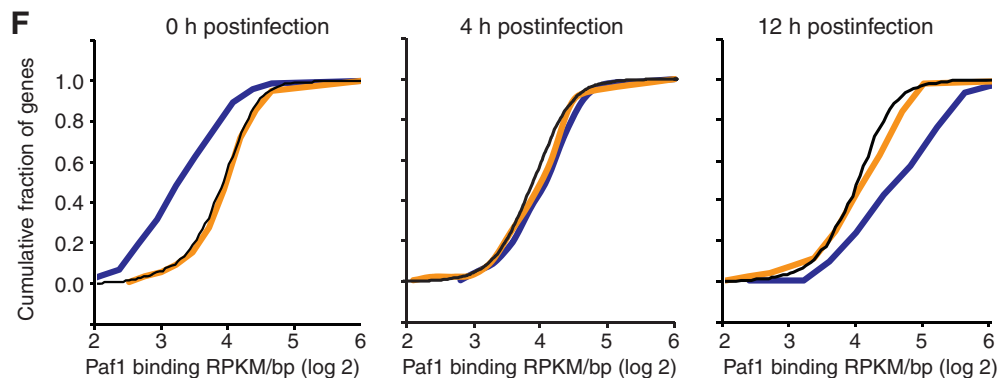

Figure 2. Virus infection leads to Paf1 recruitment to the virus-activated gene loci. (A) A549 lung epithelia cells were infected with PR8/ $\triangle \mathrm{NS} 1$ virus that due to the lack of NS1 induces strong antiviral responses. The virus infection resulted in time-dependent increase (red) or decrease (blue) in Pafl binding. The heatmap shows relative abundance of Pafl binding to the gene transcriptional start sites (TSSs) in control or infected cells as determined by ChIP sequencing. Gray boxes at the right of the heat map indicate known interferon-stimulated genes (ISGs) (Schoggins et al. 2011). (B) The table shows the top five functional categories associated with genes that display $>2$-fold change in Pafl binding at $12 \mathrm{~h}$ after infection. $(C)$ Virus infection increases Pafl abundance at key antiviral genes. Binding of H3K4me3 (green), Paf1 (blue), and Pol II (black) at virus-induced genes in noninfected cells $(0 \mathrm{~h})$ and PR8/ $\Delta \mathrm{NS} 1-$ infected cells at $4 \mathrm{~h}$ and $12 \mathrm{~h}$ postinfection is shown. The $y$-axes represent the average number of tags per gene per 25 base pairs per 1,000,000 mapped reads. Scale values are indicated in parentheses. $(D)$ Virus-induced Pafl binding correlates with recruitment of RNA Pol II to antiviral gene loci. The plot shows the cumulative distribution function (CDF) of changes in Pol II binding to different groups of Pol II- or Pafl-bound genes at $12 \mathrm{~h}$ postinfection with influenza PR8/DNS1. Genes that change Paf1 binding upon infection: red line; all genes that bind Paf1: black line; all genes that bind Pol II: green line. The dashed gray line indicates a fold change of $1 .(E)$ Virus-induced Pafl binding correlates with up-regulation of antiviral gene expression. The plot shows the CDF of changes in gene expression for different groups of Pafl-associated genes at $12 \mathrm{~h}$ postinfection with influenza PR8/ $\Delta$ NS1. Genes that change Paf1 binding upon infection: red line; all genes that bind Pafl: black line; genes that do not bind to Pafl: blue line; all genes: yellow line. The dashed gray line indicates a fold change of 1. $(F)$ Pafl deficiency down-regulates selectively expression of genes that recruit Pafl during infection. The plot shows the CDF of Pafl-binding levels ( $\log 2 \mathrm{RPKM} / \mathrm{bp})$ in noninfected A549 cells (left), in A549 cells $4 \mathrm{~h}$ postinfection with influenza PR8/DNS1 (middle), or $12 \mathrm{~h}$ postinfection (right) for genes that were suppressed by Paf1 knockdown (dark blue line), up-regulated by Pafl deficiency (orange line), or for all genes (black line). 
BRD4 as well as related BRDT, BRD2, and BRD3 proteins of the BET family (Dey et al. 2000, 2003; Kanno et al. 2004; Huang et al. 2007). The mechanism by which individual BETs contribute to gene regulation is not fully understood. BRD4 is the only BET protein that links acetylated chromatin to the $\mathrm{P}-\mathrm{TEFb}$ complex that mediates the signal-induced phosphorylation and activation of RNA Pol II (Jang et al. 2005; Yang et al. 2005; Hargreaves et al. 2009; Zhou et al. 2012). BET proteins can also contribute to RNA synthesis by a bromodomain-independent association with Paf1C as well as with numerous effector proteins such as NSD3, a SET domain-containing histone methyltransferase; JMJD6, a histone arginine demethylase; or Chd4, a catalytic component of the
NuRD nucleosome remodeling complex (Rahman et al. 2011; Liu et al. 2013).

We were the first to show the powerful anti-inflammatory effect of synthetic antagonists of BET bromodomains (Nicodeme et al. 2010). The pharmacological inhibitor of BET proteins that we named I-BET binds to the acetylated lysine-binding pockets of BET proteins and prevents these proteins from interacting with their cognate acetyl-lysine ligands (Nicodeme et al. 2010). In addition to suppression of inflammatory genes, the inhibitor of BET proteins (I-BET) possesses a remarkable capacity to inhibit expression of numerous inducible genes, including those that are driven by transcription factors such as c-Myc in tumor cells (Dawson et al. 2011; Delmore et al.

A
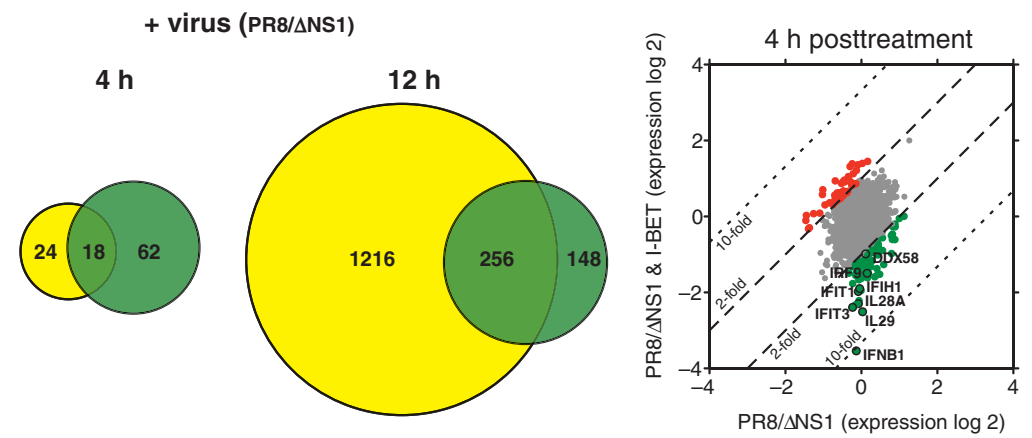

B

$$
+ \text { IFN } \beta
$$


Figure 3. I-BET suppresses the antiviral response. $(A)$ Venn diagrams display the number of virus-induced genes ( $>$ twofold, yellow circle) that were suppressed ( $>$ twofold, green circle) by I-BET treatment of A549 cells at $4 \mathrm{~h}$ or $12 \mathrm{~h}$ postinfection with influenza $\mathrm{PR} 8 / \Delta \mathrm{NS} 1$. The scatter plot shows gene expression levels in control ( $x$-axis) vs. I-BET-treated cells $(y$-axis) at $4 \mathrm{~h}$ postinfection. The down- or up-regulated genes are shown in green or red, respectively. A black circle highlights genes that have an important role in antiviral response. The dashed black line indicates a twofold change in expression; the dotted black line indicates a 10-fold change in expression. (B) Venn diagrams display the number of IFN $\beta$-induced genes ( $>$ twofold, orange circle) that were suppressed ( $>$ twofold, green circle) by I-BET treatment of A549 cells at $4 \mathrm{~h}$ or $12 \mathrm{~h}$ after incubation with IFN $\beta$. The scatter plot shows gene expression levels in control ( $x$-axis) vs. I-BET-treated cells ( $y$-axis) at $4 \mathrm{~h}$ after IFN $\beta$ treatment. The down- or up-regulated genes are shown in green or red, respectively. A black circle highlights examples of genes that have an important role in the cellular antiviral response. The dashed black line indicates a twofold change in expression; the dotted black line indicates a 10-fold change in expression. (C) I-BET increases virus growth in vitro. The kinetics of influenza PR8/ $\Delta$ NS1 virus replication in control (black circles) or I-BET-treated A549 cells (red circles) has been measured as described (Marazzi et al. 2012). The viral replication in I-BET-treated cells was compared with viral replication in Pafl-deficient A549 cells (blue triangles) that display significant increase in viral replication when compared with control cells (black triangles). 
2011; Zuber et al. 2011; Loven et al. 2013), NF-кB in macrophages (Nicodeme et al. 2010; Belkina et al. 2013), or OCA-B in B cells (Chapuy et al. 2013). In a certain sense, I-BET appears as a chemical equivalent of a histone SLiM and hence could be qualified as a synthetic histone mimic.

We found that similar to PaflC, the BET proteins have an important role in regulation of antiviral gene expression and antiviral defense. Incubation of A549 cells with I-BET resulted in greatly attenuated expression of 18 and 256 genes induced by infection with influenza A PR8/ $\Delta \mathrm{NS} 1$ at $4 \mathrm{~h}$ and $12 \mathrm{~h}$ postinfection, respectively (Fig. 3A). The impact of I-BET on antiviral gene expression reflects the ability of the inhibitor to suppress expression of the virus-induced type I/III IFN genes as well as multiple ISGs. Incubation with I-BET led to down-regulation of 45 and 75 ISGs in A549 cells treated with IFNß at $4 \mathrm{~h}$ and $12 \mathrm{~h}$ poststimulation, respectively (Fig. 3B). The suppressive effect of I-BET on antiviral gene expression was associated with greatly increased cell susceptibility to viral infection. Similar to Pafl-deficient cells, the I-BETtreated A549 cells display a nearly 10-fold increase in levels in replication of NS1-deficient influenza A PR8/ $\Delta$ NS1 when compared with nontreated cells (Fig. 3C).

The profound and selective impact of I-BET on antiviral gene expression in infected cells is similar to a negative effect of NS1 on the antiviral state of the infected cells. Assuming that the histone mimic mediates a significant part of the NS1 effect on gene expression, our finding shows a remarkable similarity between natural, for example, the NS1 tail and synthetic, for example, I-BET, histone mimics.

\section{CONCLUSION}

Our finding identifies the ability of viral and synthetic histone mimics to interfere with the formation of transcriptional complexes and gene expression. We show that the immunosuppressive NS1 protein of influenza A virus uses histone mimicry for suppression of antiviral gene expression. We also show the potent role of synthetic histone mimics in suppression of antiviral response.

The presence of histone mimics in structurally distinct viral proteins (Table 2) underscores the ability of viruses to use highly evolvable host protein sequences for developing the optimal strategy for pathogen-host interaction. By imitating histones, the viruses can challenge the adaptive capacity of the host that cannot modify the histone primary sequences without endangering the very foundation of eukaryotic cell organization. Therefore, it's plausible that many of the histone-modifying enzymes that operate in the nucleus have a dual function, both as regulator of host gene expression as well as possible modifiers and attenuators of the viral histone mimic function.

Table 2. A variety of human pathogens bear putative histone-like sequences

\begin{tabular}{|c|c|c|c|c|c|}
\hline Viral protein with H3K4-like sequence & Accession & Motif & $\begin{array}{l}\text { Distance } \\
\text { from } \\
\text { terminus }\end{array}$ & Terminus & Localization \\
\hline $\begin{array}{l}\text { Nonstructural protein } 1 \text { [Influenza A virus } \\
\text { (A/New York/392/2004(H3N2))] }\end{array}$ & YP_308845.1 & ARSK & 4 & Carboxyl & Nuclear \\
\hline $\begin{array}{l}\text { DNA polymerase catalytic subunit [Human herpesvirus } \\
6 \mathrm{~A}]\end{array}$ & NP_042931.1 & ARSK & 72 & Amino & Nuclear \\
\hline E2 protein [Semliki forest virus] & NP_819006.1 & ARSK & 31 & Carboxyl & Membrane \\
\hline Attachment glycoprotein G [Human metapneumovirus] & YP_012612.1 & ARSK & 23 & Amino & $\begin{array}{c}\text { Membrane/ } \\
\text { cytoplasm }\end{array}$ \\
\hline Truncated structural polyprotein [Semliki forest virus] & YP_006390078.1 & ARSK & 106 & Carboxyl & $\begin{array}{c}\text { Membrane/ } \\
\text { cytoplasm }\end{array}$ \\
\hline NS5b [Hepatitis C virus genotype 3] & YP_001491557.1 & ARSK & 97 & Amino & Perinuclear \\
\hline Envelope glycoprotein B [Human herpesvirus 5] & YP_081514.1 & ARSK & 257 & Amino & $\begin{array}{r}\text { Membrane/ } \\
\text { perinuclear }\end{array}$ \\
\hline HCV polyprotein [Hepatitic C virus genotype 4] & YP_001469632.1 & ARSK & 494 & Carboxyl & Varied \\
\hline Polyprotein [Hepatitis C virus genotype 5] & YP_001469633.1 & ARSK & 494 & Carboxyl & Varied \\
\hline Polyprotein [Hepatitis C virus genotype 2] & YP_001469630.1 & ARSK & 494 & Carboxyl & Varied \\
\hline Viral protein with H3K9/H3K27-like sequence & Accession & Motif & $\begin{array}{l}\text { Distance } \\
\text { from } \\
\text { terminus }\end{array}$ & Terminus & Localization \\
\hline Pol [Human adenovirus 35] & AP_000576.1 & ARKS & 28 & Amino & Nuclear \\
\hline DNA polymerase [Human adenovirus B] & YP_002213842.1 & ARKS & 28 & Amino & Nuclear \\
\hline Encapsidation protein IVa2 [Human adenovirus C] & NP_040515.1 & ARKT & 5 & Carboxyl & Nuclear \\
\hline IVa2 [Human adenovirus 2] & AP_000165.1 & ARKT & 5 & Carboxyl & Nuclear \\
\hline IVa2 [Human adenovirus 5] & AP_000201.1 & ARKT & 5 & Carboxyl & Nuclear \\
\hline IVa2 [Human adenovirus 1] & AP_000502.1 & ARKT & 5 & Carboxyl & Nuclear \\
\hline E2 protein [Human papillomavirus type 88 ] & YP_001672011.1 & ARKS & 52 & Amino & Nuclear \\
\hline $\begin{array}{l}\text { Single-stranded DNA-binding protein [Human } \\
\text { adenovirus D] }\end{array}$ & YP_001974427.1 & ARKT & 72 & Amino & Nuclear \\
\hline ORF29 [Human herpesvirus 8] & YP_001129382.1 & ARKT & 126 & Amino & Nuclear \\
\hline BALF5 [Human herpesvirus 4] & YP_401712.1 & ARKT & 60 & Carboxyl & Nuclear \\
\hline
\end{tabular}

The viral proteins that are homologous to the $\mathrm{H} 3 \mathrm{~K} 4$ or $\mathrm{H} 3 \mathrm{~K} 9 / \mathrm{H} 3 \mathrm{~K} 27$ sequences in histone $\mathrm{H} 3$ are shown. The position of the putative viral histone mimics, with respect to the carboxyl or amino termini, as well as the cellular localization of the viral proteins, is indicated. 
In support of this model, acetylation of the histone mimic within NS1, that prevents its binding to Paf1C (Marazzi et al. 2012), could be seen as a part of the host defense against the virus. Accordingly, identification of enzymes that modify viral mimics may lead to the development of novel antiviral drugs.

Histone mimics may not only potentiate the ability of the virus to interfere with the host but also increase virus dependence on host transcription. It is tempting to speculate that by using histone mimicry the viruses may become more dependent on the host. As a consequence, the histone-mimic-bearing viruses or other pathogens may evolve eventually as symbiotic pathogens in a fashion similar to the commensal organisms in humans and animals.

The synthetic histone mimics such as the BET inhibitor I-BET or, similar to it, JQ1 (Filippakopoulos et al. 2010) can interfere with a significant number of genes largely overlapping but subtly different, including those triggered by viruses. This effect of BET inhibitors relies on a highly specific interaction with the bromodomains of the BET family of proteins. By using the analogy to SLiMs, it is possible to speculate that minor changes in the structure of BET inhibitors, although altering the inhibitor binding to BET proteins, may reveal therapeutically relevant drug targets that could not have been predicted based on the rational design that commonly ignores the founding role of SLiM in protein-protein interaction.

\section{ACKNOWLEDGMENTS}

We thank Adolfo Garcia-Sastre for providing the PR8/DNS1 virus; Raphael Cohn for performing ChIPsequencing experiments; The Rockefeller University Genomics Resource Center; and Jonas Marcello and Ryan Kim for assistance with the data analysis. This work has been supported by a Lupus Foundation Grant (A.T.), The Rockefeller University and the Epinova DPU, ImmunoInflammation Therapy Area, and GlaxoSmithKline (A.T., U.S., and R.P.).

\section{REFERENCES}

Ashour J, Laurent-Rolle M, Shi PY, Garcia-Sastre A. 2009. NS5 of dengue virus mediates STAT2 binding and degradation. $J$ Virol 83: 5408-5418.

Badeaux AI, Shi Y. 2013. Emerging roles for chromatin as a signal integration and storage platform. Nat Rev Mol Cell Biol 14: $211-224$.

Ballestas ME, Chatis PA, Kaye KM. 1999. Efficient persistence of extrachromosomal KSHV DNA mediated by latency-associated nuclear antigen. Science 284: 641-644.

Banerjee P, DeJesus R, Gjoerup O, Schaffhausen BS. 2013. Viral interference with DNA repair by targeting of the single-stranded DNA binding protein RPA. PLoS Pathog 9: e1003725.

Bao Y, Bolotov P, Dernovoy D, Kiryutin B, Zaslavsky L, Tatusova T, Ostell J, Lipman D. 2008. The influenza virus resource at the National Center for Biotechnology Information. $J$ Virol 82: $596-601$.

Belkina AC, Nikolajczyk BS, Denis GV. 2013. BET protein function is required for inflammation: Brd2 genetic disruption and BET inhibitor JQ1 impair mouse macrophage inflammatory responses. J Immunol 190: 3670-3678.

Chapuy B, McKeown MR, Lin CY, Monti S, Roemer MG, Qi J, Rahl PB, Sun HH, Yeda KT, Doench JG, et al. 2013. Discovery and characterization of super-enhancer-associated dependencies in diffuse large B cell lymphoma. Cancer Cell 24: 777-790.

Chua MA, Schmid S, Perez JT, Langlois RA, Tenoever BR. 2013. Influenza A virus utilizes suboptimal splicing to coordinate the timing of infection. Cell Rep 3: 23-29.

Collins RE, Northrop JP, Horton JR, Lee DY, Zhang X, Stallcup MR, Cheng X. 2008. The ankyrin repeats of G9a and GLP histone methyltransferases are mono- and dimethyllysine binding modules. Nat Struct Mol Biol 15: 245-250.

Colpitts TM, Barthel S, Wang P, Fikrig E. 2011. Dengue virus capsid protein binds core histones and inhibits nucleosome formation in human liver cells. PLoS One 6: e24365.

Davey NE, Trave G, Gibson TJ. 2011. How viruses hijack cell regulation. Trends Biochem Sci 36: 159-169.

Davey NE, Van Roey K, Weatheritt RJ, Toedt G, Uyar B, Altenberg B, Budd A, Diella F, Dinkel H, Gibson TJ. 2012. Attributes of short linear motifs. Mol Biosyst 8: 268-281.

Dawson MA, Prinjha RK, Dittmann A, Giotopoulos G, Bantscheff M, Chan WI, Robson SC, Chung CW, Hopf C, Savitski MM, et al. 2011. Inhibition of BET recruitment to chromatin as an effective treatment for MLL-fusion leukaemia. Nature 478: $529-533$.

Delmore JE, Issa GC, Lemieux ME, Rahl PB, Shi J, Jacobs HM, Kastritis E, Gilpatrick T, Paranal RM, Qi J, et al. 2011. BET bromodomain inhibition as a therapeutic strategy to target c-Myc. Cell 146: 904-917.

Dey A, Ellenberg J, Farina A, Coleman AE, Maruyama T, Sciortino S, Lippincott-Schwartz J, Ozato K. 2000. A bromodomain protein, MCAP, associates with mitotic chromosomes and affects G(2)-to-M transition. Mol Cell Biol 20: 65376549.

Dey A, Chitsaz F, Abbasi A, Misteli T, Ozato K. 2003. The double bromodomain protein Brd4 binds to acetylated chromatin during interphase and mitosis. Proc Natl Acad Sci 100: 8758-8763.

Diella F, Haslam N, Chica C, Budd A, Michael S, Brown NP, Trave G, Gibson TJ. 2008. Understanding eukaryotic linear motifs and their role in cell signaling and regulation. Front Biosci 13: 6580-6603

Dinkel H, Van Roey K, Michael S, Davey NE, Weatheritt RJ, Born D, Speck T, Kruger D, Grebnev G, Kuban M, et al. 2014. The eukaryotic linear motif resource ELM: 10 years and counting. Nucleic Acids Res 42: D259-D266.

Donlin LT, Andresen C, Just S, Rudensky E, Pappas CT, Kruger M, Jacobs EY, Unger A, Zieseniss A, Dobenecker MW, et al. 2012. Smyd2 controls cytoplasmic lysine methylation of Hsp90 and myofilament organization. Genes Dev 26: 114119.

Dover J, Schneider J, Tawiah-Boateng MA, Wood A, Dean K, Johnston M, Shilatifard A. 2002. Methylation of histone H3 by COMPASS requires ubiquitination of histone $\mathrm{H} 2 \mathrm{~B}$ by Rad6. J Biol Chem 277: 28368-28371.

Edwards RJ, Davey NE, O’Brien K, Shields DC. 2012. Interactome-wide prediction of short, disordered protein interaction motifs in humans. Mol Biosyst 8: 282-295.

Elde NC, Malik HS. 2009. The evolutionary conundrum of pathogen mimicry. Nat Rev Microbiol 7: 787-797.

Filippakopoulos P, Qi J, Picaud S, Shen Y, Smith WB, Fedorov O, Morse EM, Keates T, Hickman TT, Felletar I, et al. 2010. Selective inhibition of BET bromodomains. Nature 468: 1067-1073.

Fischle W, Wang Y, Allis CD. 2003. Histone and chromatin cross-talk. Curr Opin Cell Biol 15: 172-183.

Fonseca GJ, Thillainadesan G, Yousef AF, Ablack JN, Mossman KL, Torchia J, Mymryk JS. 2012. Adenovirus evasion of interferon-mediated innate immunity by direct antagonism of a cellular histone posttranslational modification. Cell Host Microbe 11: 597-606. 
Fonseca GJ, Cohen MJ, Nichols AC, Barrett JW, Mymryk JS 2013. Viral retasking of $h B r e 1 / R N F 20$ to recruit hPafl for transcriptional activation. PLoS Pathog 9: e1003411.

Friborg J Jr, Kong W, Hottiger MO, Nabel GJ. 1999. p53 inhibition by the LANA protein of KSHV protects against cell death. Nature 402: 889-894.

Fujimuro M, Wu FY, ApRhys C, Kajumbula H, Young DB, Hayward GS, Hayward SD. 2003. A novel viral mechanism for dysregulation of beta-catenin in Kaposi's sarcoma-associated herpesvirus latency. Nat Med 9: 300-306.

Garcia-Sastre A, Biron CA. 2006. Type 1 interferons and the virus-host relationship: A lesson in detente. Science 312: 879-882.

Garcia-Sastre A, Egorov A, Matassov D, Brandt S, Levy DE, Durbin JE, Palese P, Muster T. 1998. Influenza A virus lacking the NS1 gene replicates in interferon-deficient systems. Virology 252: 324-330.

Golebiewski L, Liu H, Javier RT, Rice AP. 2011. The avian influenza virus NS1 ESEV PDZ binding motif associates with Dlg1 and Scribble to disrupt cellular tight junctions. J Virol 85: 10639-10648.

Greenspan D, Palese P, Krystal M. 1988. Two nuclear location signals in the influenza virus NS1 nonstructural protein. $J$ Virol 62: 3020-3026.

Hahn MA, Dickson KA, Jackson S, Clarkson A, Gill AJ, Marsh DJ. 2012. The tumor suppressor CDC73 interacts with the ring finger proteins RNF20 and RNF40 and is required for the maintenance of histone 2B monoubiquitination. Hum Mol Genet 21: 559-568.

Hargreaves DC, Horng T, Medzhitov R. 2009. Control of inducible gene expression by signal-dependent transcriptional elongation. Cell 138: 129-145.

Hopfield JJ. 1974. Kinetic proofreading: A new mechanism for reducing errors in biosynthetic processes requiring high specificity. Proc Natl Acad Sci 71: 4135-4139.

Huang H, Zhang J, Shen W, Wang X, Wu J, Shi Y. 2007. Solution structure of the second bromodomain of $\mathrm{Brd} 2$ and its specific interaction with acetylated histone tails. BMC Struct Biol 7: 57.

Jackson D, Hossain MJ, Hickman D, Perez DR, Lamb RA. 2008. A new influenza virus virulence determinant: The NS1 protein four C-terminal residues modulate pathogenicity. Proc Natl Acad Sci 105: 4381-4386.

Jang MK, Mochizuki K, Zhou M, Jeong HS, Brady JN, Ozato K. 2005. The bromodomain protein Brd4 is a positive regulatory component of $\mathrm{P}-\mathrm{TEFb}$ and stimulates RNA polymerase IIdependent transcription. Mol Cell 19: 523-534.

Kanno T, Kanno Y, Siegel RM, Jang MK, Lenardo MJ, Ozato K. 2004. Selective recognition of acetylated histones by bromodomain proteins visualized in living cells. Mol Cell 13: 33-43.

Katze MG, He Y, Gale M Jr. 2002. Viruses and interferon: A fight for supremacy. Nat Rev Immunol 2: 675-687.

Kawai T, Akira S. 2006. Innate immune recognition of viral infection. Nat Immunol 7: 131-137.

Kim J, Roeder RG. 2009. Direct Bre1-Paf1 complex interactions and RING finger-independent Bre1-Rad6 interactions mediate histone H2B ubiquitylation in yeast. J Biol Chem 284: 20582-20592

Kim J, Guermah M, Roeder RG. 2010. The human PAF1 complex acts in chromatin transcription elongation both independently and cooperatively with SII/TFIIS. Cell 140: 491-503.

Krug RM, Yuan W, Noah DL, Latham AG. 2003. Intracellular warfare between human influenza viruses and human cells: The roles of the viral NS1 protein. Virology 309: 181-189.

Lee JS, Kim Y, Kim IS, Kim B, Choi HJ, Lee JM, Shin HJ, Kim JH, Kim JY, Seo SB, et al. 2010. Negative regulation of hypoxic responses via induced Reptin methylation. Mol Cell 39: $71-85$

Lee JM, Lee JS, Kim H, Kim K, Park H, Kim JY, Lee SH, Kim IS, Kim J, Lee M, et al. 2012. EZH2 generates a methyl degron that is recognized by the DCAF1/DDB1/CUL4 E3 ubiquitin ligase complex. Mol Cell 48: 572-586.
Liu L, Oliveira NM, Cheney KM, Pade C, Dreja H, Bergin AM, Borgdorff V, Beach DH, Bishop CL, Dittmar MT, et al. 2011. A whole genome screen for HIV restriction factors. Retrovirology 8: 94 .

Liu W, Ma Q, Wong K, Li W, Ohgi K, Zhang J, Aggarwal AK, Rosenfeld MG. 2013. Brd4 and JMJD6-associated anti-pause enhancers in regulation of transcriptional pause release. Cell 155: $1581-1595$.

Loven J, Hoke HA, Lin CY, Lau A, Orlando DA, Vakoc CR, Bradner JE, Lee TI, Young RA. 2013. Selective inhibition of tumor oncogenes by disruption of super-enhancers. Cell 153: $320-334$

Marazzi I, Ho JS, Kim J, Manicassamy B, Dewell S, Albrecht RA, Seibert CW, Schaefer U, Jeffrey KL, Prinjha RK, et al. 2012. Suppression of the antiviral response by an influenza histone mimic. Nature 483: 428-433.

Mueller CL, Porter SE, Hoffman MG, Jaehning JA. 2004. The Pafl complex has functions independent of actively transcribing RNA polymerase II. Mol Cell 14: 447-456.

Nagaike T, Logan C, Hotta I, Rozenblatt-Rosen O, Meyerson M, Manley JL. 2011. Transcriptional activators enhance polyadenylation of mRNA precursors. Mol Cell 41: 409-418.

Nakanishi S, Lee JS, Gardner KE, Gardner JM, Takahashi YH, Chandrasekharan MB, Sun ZW, Osley MA, Strahl BD, Jaspersen SL, et al. 2009. Histone H2BK123 monoubiquitination is the critical determinant for $\mathrm{H} 3 \mathrm{~K} 4$ and H3K79 trimethylation by COMPASS and Dot1. J Cell Biol 186: 371-377.

Nemeroff ME, Barabino SM, Li Y, Keller W, Krug RM. 1998. Influenza virus NS1 protein interacts with the cellular $30 \mathrm{kDa}$ subunit of CPSF and inhibits $3^{\prime}$ end formation of cellular premRNAs. Mol Cell 1: 991-1000.

Nicodeme E, Jeffrey KL, Schaefer U, Beinke S, Dewell S, Chung CW, Chandwani R, Marazzi I, Wilson P, Coste H, et al. 2010. Suppression of inflammation by a synthetic histone mimic. Nature 468: 1119-1123.

Ninio J. 1975. Kinetic amplification of enzyme discrimination. Biochimie 57: 587-595.

Nordick K, Hoffman MG, Betz JL, Jaehning JA. 2008. Direct interactions between the Pafl complex and a cleavage and polyadenylation factor are revealed by dissociation of Paf1 from RNA polymerase II. Eukaryot Cell 7: 11581167.

Obenauer JC, Denson J, Mehta PK, Su X, Mukatira S, Finkelstein DB, Xu X, Wang J, Ma J, Fan Y, et al. 2006. Large-scale sequence analysis of avian influenza isolates. Science 311: 1576-1580.

Penheiter KL, Washburn TM, Porter SE, Hoffman MG, Jaehning JA. 2005. A posttranscriptional role for the yeast Paf1RNA polymerase II complex is revealed by identification of primary targets. Mol Cell 20: $213-223$.

Rahman S, Sowa ME, Ottinger M, Smith JA, Shi Y, Harper JW, Howley PM. 2011. The Brd4 extraterminal domain confers transcription activation independent of pTEFb by recruiting multiple proteins, including NSD3. Mol Cell Biol 31: 26412652.

Rozenblatt-Rosen O, Nagaike T, Francis JM, Kaneko S, Glatt KA, Hughes CM, LaFramboise T, Manley JL, Meyerson M. 2009. The tumor suppressor Cdc 73 functionally associates with CPSF and CstF $3^{\prime}$ mRNA processing factors. Proc Natl Acad Sci 106: 755-760.

Ruthenburg AJ, Li H, Patel DJ, Allis CD. 2007. Multivalent engagement of chromatin modifications by linked binding modules. Nat Rev Mol Cell Biol 8: 983-994.

Sampath SC, Marazzi I, Yap KL, Krutchinsky AN, Mecklenbrauker I, Viale A, Rudensky E, Zhou MM, Chait BT, Tarakhovsky A. 2007. Methylation of a histone mimic within the histone methyltransferase G9a regulates protein complex assembly. Mol Cell 27: 596-608.

Santos A, Pal S, Chacon J, Meraz K, Gonzalez J, Prieto K, Rosas-Acosta G. 2013. SUMOylation affects the interferon blocking activity of the influenza A nonstructural protein NS1 without affecting its stability or cellular localization. $J$ Virol 87: 5602-5620. 
Satterly N, Tsai PL, van Deursen J, Nussenzveig DR, Wang Y, Faria PA, Levay A, Levy DE, Fontoura BM. 2007. Influenza virus targets the mRNA export machinery and the nuclear pore complex. Proc Natl Acad Sci 104: 1853-1858.

Schoggins JW, Wilson SJ, Panis M, Murphy MY, Jones CT, Bieniasz P, Rice CM. 2011. A diverse range of gene products are effectors of the type I interferon antiviral response. Nature 472: $481-485$.

Shi J, Wang Y, Zeng L, Wu Y, Deng J, Zhang Q, Lin Y, Li J, Kang T, Tao M, et al. 2014. Disrupting the Interaction of BRD4 with diacetylated twist suppresses tumorigenesis in basal-like breast cancer. Cancer Cell 25: 210-225.

Simic R, Lindstrom DL, Tran HG, Roinick KL, Costa PJ, Johnson AD, Hartzog GA, Arndt KM. 2003. Chromatin remodeling protein Chd 1 interacts with transcription elongation factors and localizes to transcribed genes. EMBO J 22: $1846-$ 1856.

Sims RJ III, Millhouse S, Chen CF, Lewis BA, ErdjumentBromage H, Tempst P, Manley JL, Reinberg D. 2007. Recognition of trimethylated histone $\mathrm{H} 3$ lysine 4 facilitates the recruitment of transcription postinitiation factors and premRNA splicing. Mol Cell 28: 665-676.

Smock RG, Gierasch LM. 2009. Sending signals dynamically. Science 324: 198-203.

Sobhian B, Laguette N, Yatim A, Nakamura M, Levy Y, Kiernan R, Benkirane M. 2010. HIV-1 Tat assembles a multifunctional transcription elongation complex and stably associates with the 7SK snRNP. Mol Cell 38: 439-451.

Stein A, Pache RA, Bernado P, Pons M, Aloy P. 2009. Dynamic interactions of proteins in complex networks: A more structured view. FEBS J 276: 5390-5405.

Sun ZW, Allis CD. 2002. Ubiquitination of histone H2B regulates $\mathrm{H} 3$ methylation and gene silencing in yeast. Nature 418: 104-108.

Tachibana M, Ueda J, Fukuda M, Takeda N, Ohta T, Iwanari H, Sakihama T, Kodama T, Hamakubo T, Shinkai Y. 2005. Histone methyltransferases G9a and GLP form heteromeric complexes and are both crucial for methylation of euchromatin at H3-K9. Genes Dev 19: 815-826.

Tarakhovsky A. 2013. Logic of the inflammation-associated transcriptional response. Adv Immunol 119: 107-133.

Taverna SD, Li H, Ruthenburg AJ, Allis CD, Patel DJ. 2007. How chromatin-binding modules interpret histone modifica- tions: Lessons from professional pocket pickers. Nat Struct Mol Biol 14: 1025-1040.

Thomas M, Kranjec C, Nagasaka K, Matlashewski G, Banks L. 2011. Analysis of the PDZ binding specificities of Influenza A virus NS1 proteins. Virol $J$ 8: 25.

Van Roey K, Gibson TJ, Davey NE. 2012. Motif switches: Decision-making in cell regulation. Curr Opin Struct Biol 22: $378-385$.

Van Roey K, Dinkel H, Weatheritt RJ, Gibson TJ, Davey NE. 2013. The switches.ELM resource: A compendium of conditional regulatory interaction interfaces. Sci Signal 6: rs7.

Wang X, Li M, Zheng H, Muster T, Palese P, Beg AA, GarciaSastre A. 2000. Influenza A virus NS1 protein prevents activation of NF-kappaB and induction of alpha/beta interferon. J Virol 74: 11566-11573.

Weatheritt RJ, Davey NE, Gibson TJ. 2012a. Linear motifs confer functional diversity onto splice variants. Nucleic Acids Res 40: $7123-7131$.

Weatheritt RJ, Luck K, Petsalaki E, Davey NE, Gibson TJ. $2012 \mathrm{~b}$. The identification of short linear motif-mediated interfaces within the human interactome. Bioinformatics 28: 976-982.

Wood A, Schneider J, Dover J, Johnston M, Shilatifard A. 2003. The Pafl complex is essential for histone monoubiquitination by the Rad6-Bre1 complex, which signals for histone methylation by COMPASS and Dot1p. J Biol Chem 278: 3473934742.

Yang Z, Yik JH, Chen R, He N, Jang MK, Ozato K, Zhou Q. 2005. Recruitment of P-TEFb for stimulation of transcriptional elongation by the bromodomain protein Brd4. Mol Cell 19: $535-545$.

You J, Croyle JL, Nishimura A, Ozato K, Howley PM. 2004. Interaction of the bovine papillomavirus $\mathrm{E} 2$ protein with $\mathrm{Brd} 4$ tethers the viral DNA to host mitotic chromosomes. Cell 117: 349-360.

Zhao RY, Elder RT. 2005. Viral infections and cell cycle G2/M regulation. Cell Res 15: 143-149.

Zhou Q, Li T, Price DH. 2012. RNA polymerase II elongation control. Annu Rev Biochem 81: 119-143.

Zuber J, Shi J, Wang E, Rappaport AR, Herrmann H, Sison EA, Magoon D, Qi J, Blatt K, Wunderlich M, et al. 2011. RNAi screen identifies Brd4 as a therapeutic target in acute myeloid leukaemia. Nature 478: 524-528. 


\section{$\$_{\text {CSH }}^{\infty}$ Cold Spring Harbor Symposia SYMPOSIA On Quantitative Biology}

\section{The "Histone Mimicry" by Pathogens}

Uwe Schaefer, Jessica S.Y. Ho, Rab K. Prinjha, et al.

Cold Spring Harb Symp Quant Biol 2013 78: 81-90 originally published online April 14, 2014 Access the most recent version at doi:10.1101/sqb.2013.78.020339

References This article cites 88 articles, 27 of which can be accessed free at: http://symposium.cshlp.org/content/78/81.full.html\#ref-list-1

\section{License}

Email Alerting Receive free email alerts when new articles cite this article - sign up in Service the box at the top right corner of the article or click here. 